\title{
ANALISIS PENALARAN PROPORSIONAL SISWA DENGAN GAYA BELAJAR AUDITORI DALAM MENYELESAIKAN SOAL PERBANDINGAN
}

\author{
Aan Putra ${ }^{1}$, Yetiona Tensa ${ }^{2}$, Selvia Erita ${ }^{3}$ \\ 1, 2, 3 Institut Agama Islam Negeri Kerinci, Jl. Muradi Sungai Liuk, Pesisir Bukit, Sungai Penuh, Jambi, Indonesia \\ aanputra283@gmail.com
}

\begin{abstract}
Abstrak
Comparison, ratio, and proportion were any problems encountered in everyday life. To understand it, highlevel proportional reasoning is needed. The analysis for this ability was important, especially on any students with an auditory learning style that rely on hearing to understand the lesson. This study attempts to describe the proportional reasoning level of students with the auditory learning style in solving the proportion problems. Research informants were selected using purposive sampling technique. Based on the results of the learning style questionnaire, the researcher obtains 5 students with an auditory learning style. The research informant was given some question about the proportion, then were they interviewed about the strategies used in solving the problems. The results of the analysis of student answers and interviews indicate that 4 in 5 students have proportional reasoning at the qualitative level. Only 1 in 5 students reach the multiplicative level.
\end{abstract}

Keywords: Proportional Reasoning, Auditory Learning Style, Proportion Problems

\begin{abstract}
Abstrak
Perbandingan, rasio dan proporsi merupakan permasalahan yang sering ditemui dalam kehidipan sehari-hari. Untuk memahaminya diperlukan kemampuan penalaran proporsional. Analisis kemampuan ini menjadi penting terutama bagi siswa dengan gaya belajar auditori yang mengandalkan pendengaran untuk memahami materi. Penelitian ini bertujuan untuk mendiskripsikan tingkat kemampuan penalaran proporsional siswa dengan gaya belajar auditori dalam menyelesaikan soal perbandingan. Informan penelitian dipilih menggunakan teknik purposive sampling. Berdasarkan hasil angket gaya belajar, ditemukan 5 siswa yang memiliki gaya belajar auditori. Setelah menyelesaikan soal perbandingan, informan penelitian diwawancarai mengenai strategi penyelesaian soal. Hasil penelitian menunjukkan bahwa 4 dari 5 siswa memiliki kemampuan penalaran proporsional level kualitatif dan hanya satu siswa yang mencapai level multiplikatif.
\end{abstract}

Kata kunci: Penalaran Proporsional, Gaya Belajar Auditori, Soal Perbandingan

\section{PENDAHULUAN}

Permasalahan matematika yang berhubungan dengan kehidupan sehari-hari dalam mata pelajaran matematika akan membuat siswa mengerti dan memahami manfaat dari ilmu yang dipelajari. Permasalahan yang muncul kadang belum ditemukan prosedur untuk menyelesaikannya sehingga dibutuhkan kemampuan penalaran (Wulansari, Putra, Rusliah \& Habibi, 2019). Penalaran merupakan kegiatan berpikir untuk menarik kesimpulan dari permasalahan yang diketahui dan ditetapkan sebelumnya (Putra, Syarifuddin \& Zulfah, 2018). Salah satu penalaran yang penting dalam pembelajaran matematika adalah penalaran proporsional.

Penalaran proporsional adalah aktivitas mental dalam pengkoordinasian dua kuantitas yang berkaitan dengan relasi perubahan (senilai atau berbalik nilai) suatu kuantitas terhadap kuantitas yang lain (Irpan, 2010). Penalaran proporsional diambil dari kata penalaran atau berpikir secara logis dan proporsional atau situasi perbandingan, sehingga dapat diartikan sebagai berpikir secara logis dalam situasi perbandingan. Hubungan-hubungan dalam situasi proporsional yang dimaksud yaitu berkaitan 
dengan konsep rasio dan proporsi. Tinggi rendahnya penalaran proporsional siswa dapat menjadi indikator penguasaaan siswa terhadap materi yang berhubungan dengan perbandingan (Sari \& Sufri, 2014). Oleh karena itu, penalaran proporsional siswa sangat penting untuk dikembangkan dengan baik. Penalaran proporsional yang kurang berkembang dapat mengakibatkan beberapa masalah, misalnya kesalahan dalam memahami pelajaran yang diberikan, kesalahan dalam memahami maksud soal, dan kesalahan dalam menjawab soal. Apabila hal ini terjadi maka nilai siswa menjadi rendah.

Berdasarkan observasi awal di SMP N 22 Kerinci yang dilakukan pada siswa kelas VII, hasil analisis jawaban ulangan siswa pada materi perbandingan dan wawancara dengan siswa mengungkapkan bahwa sebagian besar siswa tidak dapat menyelesaikan soal materi perbandingan. Padahal materi perbandingan sudah diajarkan sejak kelas V. Siswa masih terbiasa hanya terpaku pada satu penyelesaian masalah yang sama seperti yang telah dicontohkan oleh gurunya, sehingga pola pikir siswa hanya terpaku pada satu penyelesaian saja tanpa mencoba, menganalisis dan menemukan cara yang baru. Beberapa siswa juga kurang bisa memberikan kesimpulan yang jelas dan logis dari penyelesaian dari soal yang telah mereka kerjakan. Sebagian siswa masih belum bisa menyelesaikan soal perbandingan dengan jawaban yang sempurna. Masih banyak siswa yang mengalami kesulitan materi perbandingan, khususnya ketidakpahaman masalah perbandingan tertentu atau mengapa strategi yang digunakan berhasil dalam menyelesaikan masalah. Kesulitan utama yang sering ditemui adalah kurangnya pemahaman siswa terhadap soal yang diberikan, sehingga jawaban yang muncul adalah terkesan seperti acak atau menebak saja. Menurut salah satu guru matematika yang mengajar di kelas VII SMP N 22 Kerinci, siswa cenderung menghapal rumus tanpa memahami dan menalar rumus yang didapatkannya sehingga siswa mudah melupakan materi yang telah diajarkan guru. Melihat kenyataan itu, tugas guru yang utama adalah membantu siswa untuk mengembangkan penalaran proporsionalnya dengan baik.

Tidak dapat dipungkiri bahwa dalam proses pembelajaran setiap siswa memiliki karakter yang berbeda-beda. Gaya belajar merupakan cara termudah yang dimiliki oleh individu dalam menyerap, mengatur, dan mengolah informasi yang diterima. Gaya belajar yang sesuai adalah kunci keberhasilan siswa dalam belajar. Dengan menyadari hal ini, siswa mampu menyerap dan mengolah informasi dan menjadikan belajar lebih mudah dengan gaya belajar siswa sendiri. Dengan demikian, dapat dikatakan bahwa karakteristik gaya belajar yang dimiliki peserta didik merupakan salah satu modal yang berpengaruh dalam pembelajaran, pemrosesan, dan komunikasinya (Putri, Amelia \& Gusmania, 2019). Hal yang serupa, bila siswa tersebut mengetahui karakteristik gaya belajarnya sendiri maka siswa akan lebih mudah memotivasi dirinya dalam pembelajaran. Gaya belajar anak seperti pintu pembuka. Setiap butir informasi yang masuk lewat pintu terbuka lebar, akan memudahkan anak memahami informasi itu. Pada puncak pemahaman, informasi itu akan masuk ke memori jangka panjang dan tak terlupakan seumur hidup.

Karakter yang berbeda menjadikan cara mereka untuk menyerap informasi dan perlakuan 
guru pun berbeda karena cara berfikir dan kreatif siswa pun akan berbeda. Terdapat tiga jenis gaya belajar berdasarkan modalitas yang digunakan individu dalam memproses informasi yaitu gaya visual, auditori dan kinestetik. Gaya belajar visual menggunakan indera penglihatannya untuk membantunya belajar. Gaya belajar auditorial memanfaatkan kemampuan pendengaran untuk mempermudah proses belajar, sehingga akan lebih mudah menerima materi yang disajikan dengan diskusi atau tanya-jawab (Bire, Geradus \& Bire, 2014).

Pada penelitian ini peneliti hanya akan meneliti anak dengan gaya belajar auditori. Anak yang memiliki gaya belajar auditori merupakan anak yang menggunakan indra pendengarannya untuk menerima informasi. Anak auditori mengakses segala jenis bunyi dan kata yang diciptakan maupun diingat seperti musik, nada, irama, dialog internal, dan suara (Parbawa, 2018). Anak dengan gaya belajar auditori lebih cepat menangkap pelajaran dengan menggunakan diskusi verbal dan mendengarkan penyampaian dari guru. Anak dengan gaya belajar auditori akan merekam apa yang dijelaskan oleh guru dan mengulang-ulang apa yang didengarnya (Sari \& Sufri, 2014). Ini sesuai dengan metode yang digunakan guru matematika di SMP N 22 Kerinci yaitu metode ceramah, tanya jawab dan diskusi.

\section{METODE}

Jenis penelitian ini adalah penelitian kualitatif dengan metode deskriptif. Penelitian ini dilaksanakan di SMP Negeri 22 Kerinci. Subjek dalam penelitian ini adalah siswa kelas VIIA yang dipilih menggunakan teknik purposive sampling. Siswa kelas VII A dipilih karena sudah mempelajari materi perbandingan yaitu perbandingan senilai dan berbalik nilai. Pada penelitian ini, data dikumpulkan langsung oleh peneliti melalui angket gaya belajar, soal kemampuan penalaran proporsional dan pedoman wawancara.

Angket bertujuan untuk mengetahui gaya belajar siswa kelas VII A SMP Negeri 22 Kerinci. Hasil angket dianalisis untuk mengidentifikasi siswa dengan gaya belajar auditori. Siswa dengan gaya belajar auditori diberi tes penalaran proporsional dengan materi perbandingan lalu diwawancarai satu persatu. Analisis data angket dilakukan dengan menghitung jumlah nilai setiap aspek. Nilai tertinggi dari setiap aspek menyatakan kecenderungan gaya belajar siswa. Jawaban siswa dan hasil wawancara dianalisis secara deskriptif. Pengujian keabsahan data dalam penelitian ini digunakan uji kredibilitas data atau kepercayaan terhadap data hasil penelitian dengan triangulasi metode.

\section{HASIL}

\section{Hasil Angket Gaya Belajar}

Berdasarkan analisis hasil angket gaya belajar yang diisi oleh siswa kelas VII A, siswa 
dikelompokkkan berdasarkan kecenderungan gaya belajar seperti tersaji pada Tabel 1.

Tabel 1.

Hasil Angket Gaya Belajar

\begin{tabular}{|c|c|c|c|c|c|}
\hline \multirow{2}{*}{ No } & \multirow{2}{*}{ Kode Siswa } & \multicolumn{3}{|c|}{ Gaya Belajar } & \multirow{2}{*}{ Kecenderungan Gaya Belajar } \\
\cline { 2 - 5 } & & Visual & Auditori & Kinestetik & \\
\hline 1 & AM & 6 & 6 & 5 & Visual-Auditori \\
\hline 2 & AF & 9 & 4 & 6 & Visual \\
\hline 3 & AHB & 7 & 8 & 8 & Auditori-Kinestetik \\
\hline 4 & DRF & 9 & 6 & 2 & Visual \\
\hline 5 & DJS & 7 & 7 & 5 & Visual-Auditori \\
\hline 6 & DAF & 6 & 7 & 7 & Auditori-Kinestetik \\
\hline 7 & EY & 6 & 4 & 5 & Visual \\
\hline 8 & EDD & 6 & 4 & 4 & Visual \\
\hline 9 & FZS & 7 & 5 & 7 & Visual-Kinestetik \\
\hline 10 & KA & 6 & 8 & 6 & Auditori \\
\hline 11 & MMS & 7 & 6 & 5 & Visual \\
\hline 12 & MS & 9 & 7 & 6 & Visual \\
\hline 13 & NH & 4 & 7 & 5 & Auditori \\
\hline 14 & OM & 9 & 7 & 5 & Visual \\
\hline 15 & PD & 9 & 6 & 2 & Visual \\
\hline 16 & RYP & 5 & 6 & 3 & Auditori \\
\hline 17 & R & 8 & 9 & 6 & Auditori \\
\hline 18 & RA & 7 & 8 & 7 & Auditori \\
\hline 19 & SLP & 7 & 7 & 7 & Visual-Auditori-Kinestetik \\
\hline 20 & YM & 4 & 6 & 6 & Auditori-Kinestetik \\
\hline 21 & YS & 7 & 7 & 4 & Visual-Auditori \\
\hline 22 & EH & 7 & 6 & 5 & Visual \\
\hline 23 & WM & 7 & 6 & 7 & Visual-Kinestetik \\
\hline & & & & & 5 \\
\hline
\end{tabular}

Berdasarkan Tabel 1, terdapat 5 orang dengan kecenderungan gaya belajar auditori, 9 orang cenderung memiliki gaya belajar visual dan tidak ada yang dominan memiliki kecenderungan gaya belajar kinestetik. Selain itu, 9 orang lainnya cenderung memiliki dua atau tiga gaya belajar sekaligus. 5 orang siswa dengan gaya belajar auditori yaitu NH, KA, RYP, R dan RA dipilih sebagai subjek penelitian dan diberikan tes penalaran proporsional.

\section{Hasil Tes Penalaran Proporsional}

\section{Penalaran Proporsional Siswa Tiap Indikator}

Berdasarkan hasil analisis data, diketahui bahwa subjek penelitian telah memenuhi indikator pertama yaitu menemukan kuantitas yang ingin dibandingkan pada semua soal yang diberikan. Kelima siswa dengan gaya belajar auditori mampu menunjukkan apa yang diketahui dan ditanyakan dari soal. Ini berarti 100\% siswa memenuhi indikator pertama penalaran proporsional. Selain itu untuk indikator kedua, memahami hubungan antar kuantitas, berdasarkan lembar jawaban tes dan hasil wawancara dapat dilihat bahwa semua siswa dengan gaya belajar auditori mampu menemukan proporsi/perbandingan dari hubungan antar kuantitas. 
Pada indikator ketiga, menggunakan strategi yang tepat, kelima siswa dengan gaya belajar auditori dapat menggunakan strategi yang tepat atau benar dalam memecahkan masalah yaitu menggunakan strategi persamaan, strategi operator dan strategi faktor perubahan (Suryadi, 2017). Ketiga strategi tersebut merupakan strategi yang benar dalam menyelesaikan penalaran proporsional. Meskipun kelima siswa menggunakan strategi yang benar dalam menyelesaikan soal penalaran proporsional tetapi hanya satu siswa (KA) yang dapat memahami dan mengerti tentang strategi yang digunakannya dalam menyelesaikan soal penalaran proporsional. Empat siswa lainnya yaitu NH, RYP, $\mathrm{R}$ dan RA tidak memahami dasar konseptual pada strategi yang digunakannya, hanya menjelaskan bahwa strategi yang digunakannya sudah ada di buku atau sudah pernah diajarkan oleh guru di kelas. Ini berarti siswa cenderung hanya menghapal rumus praktis yang sudah tersedia di buku atau menghapal contoh soal yang diberikan oleh guru pada saat pembelajaran.

Dapat disimpulkan bahwa empat dari lima siswa dengan gaya belajar auditori tidak dapat menggunakan strategi yang benar karena tidak mengetahui konsep yang akan digunakan. Sehingga langkah-langkah yang tertulis hanya berupa teknis tanpa menggunakan penalaran proporsional. Siswa auditori hanya terpaku dengan penjelasan guru dan mengandalkan kemampuan untuk mengingat. Siswa auditori dalam menyelesaikan soal lebih menggunakan apa yang ditemukannya bukan menggunakan konsep yang telah didapatkan sebelumnya. Konsep yang didapatkan siswa auditori lebih dalam bentuk hapalan bukan pemahaman siswa terhadap konsep yang ada untuk menyelesaikan soal. Sejalan dengan pendapat Marpaung (2016) yang menyatakan bahwa anak yang gaya belajar auditori dapat belajar lebih cepat dengan menggunakan diskusi verbal dan mendengarkan apa yang guru katakan, serta lebih senang pembelajaran dengan menggunakan media audio. Siswa yang memilki gaya belajar auditori lebih suka belajar diskusi, dan menyukai guru yang menjelaskan materi secara lisan.

\section{Level Penalaran Proporsional Siswa dengan Gaya Belajar Auditori}

Berdasarkan jawaban dan hasil wawancara dengan kelima siswa dalam menyelesaikan soal nomor 1 diketahui bahwa hanya satu siswa yaitu KA yang dapat memahami soal dan dapat menjelaskan strategi yang digunakannya secara konseptual. Kemungkinan besar KA menggunakan level penalaran pra-multiplikatif atau penalaran multiplikatif, karena soal pertama hanya mengunakan pengali bilangan bulat. Jika jawaban KA pada soal kedua benar, maka penalaran KA merupakan penalaran multiplikatif. Tapi jika salah, maka penalaran KA merupakan penalaran pra-multiplikatif karena hanya mampu menjawab soal dengan bilangan pengali bulat. Sedangkan keempat subjek lainnya yaitu NH, RYP, R, dan RA berada dalam level kualitatif dalam menyelesaikan soal pertama karena belum dapat menjelaskan secara konseptual.

Pada penyelesaian soal nomor 2 untuk mencari satu nilai yang belum diketahui pada suatu perbandingan senilai dengan bilangan bulat, hanya $\mathrm{R}$ yang memberikan jawaban salah. Berdasarkan wawancara diketahui bahwa siswa $\mathrm{R}$ memberikan jawaban yang salah karena tidak mengerti cara 
menggunakan operasi hitung bentuk pecahan atau decimal. Dalam menyelesaikan soal nomor 2, kelima siswa menggunakan strategi yang berbeda dalam menyelesaikan soal. NH dan R menggunakan strategi persamaan, KA dan RYP menggunakan strategi operator dan RA menggunakan strategi faktor perubahan. Tiga strategi tersebut merupakan strategi yang benar dalam menyelesaikan penalaran proporsional. Meskipun strategi yang digunakan benar, tetapi hanya siswa KA yang mampu menjelaskan jawaban yang dituliskannya secara konseptual. NH, RYP, R dan RA hanya mengungkapkan bahwa rumusnya seperti itu atau seperti itu yang dijelaskan oleh guru.

Berdasarkan hasil tes dan wawancara dapat disimpulkan bahwa hanya KA yang menggunakan level penalaran multiplikatif, karena dapat menyelesaikan soal dengan benar dengan menggunakan bilangan bulat maupun bilangan pecahan atau desimal. Sedangkan NH, RYP, R dan RA berada dalam level kualitatif dalam menyeleaikan soal nomor 2 karena belum dapat menjelaskan jawabannya secara konseptual dan hanya mampu menunjukkan hubungan antar kuantitas secara kualitatif, yaitu jika kuantitas yang satu semakin besar, maka kuantitas yang lain semakin besar pula, dan sebaliknya

Dalam menyelesaikan soal nomor 3, untuk mencari satu nilai yang belum diketahui pada suatu perbandingan berbalik nilai dengan bilangan bulat, satu siswa memberikan jawaban yang salah. Berdasarkan hasil tes diketahui bahwa siswa RA memberikan jawaban yang salah dikarenakan menjawab soal dengan asal-asalan, tanpa tau kenapa strategi tersebut digunakan. Berdasarkan hasil tes pada soal nomor 4, 5 dan 6, hanya KA yang dapat memahami soal dan dapat menjelaskan jawaban yang dituliskannya secara konseptual. Ini semakin menguatkan bahwa KA menggunakan level penalaran multiplikatif. Subjek penelitian lainnya berada dalam level kualitatif.

Secara umum, penalaran proporsional siswa dengan gaya belajar auditori kelas VII A tergolong belum cukup baik. Empat dari lima siswa dengan gaya belajar auditori belum mencapai level 5 yaitu level multiplikatif bahkan hanya berada pada level 1 yaitu level kualitatif. Hal tersebut terlihat ketika siswa menjelaskan bahwa jika kuantitas yang satu semakin besar, maka kuantitas yang lain semakin besar pula, dan sebaliknya dan siswa juga tidak mengerti dan memahami dasar konseptualnya. Siswa dengan level 5 atau level multiplikatif mampu memilih dan menggunakan strategi serta memahaminya dengan baik dan mengerti dasar konseptualnya (Nugraha, Sujadi \& Pangadi, 2016). Pada penelitian ini hanya satu orang yang mencapai level penalaran multiplikatif.

Rendahnya level penalaran proporsional siswa dimungkinkan oleh beberapa sebab yaitu siswa belum dapat memahami dasar konseptual pada strategi yang digunakannya; siswa hanya terpaku pada cara yang diajarkan oleh guru dan mengandalkan kemampuan untuk mengingat; siswa lebih menggunakan apa yang ditemukannya bukan menggunakan konsep yang telah didapatkan sebelumnya. Konsep yang didapatkan siswa lebih dalam bentuk hapalan bukan pemahaman siswa terhadap konsep yang ada untuk menyelesaikan soal. 
Analisis Penalaran Proporsional Siswa Dengan Gaya Belajar Auditori Dalam Menyelesaikan Soal Perbandingan, Aan Putra, Yetiona Tensa, Selvia Erita

\section{KESIMPULAN}

Berdasarkan hasil penelitian dapat diambil kesimpulan bahwa siswa dengan gaya belajar auditori belum memenuhi indikator ketiga penalaran proporsional, yaitu menggunakan strategi yang tepat,.dalam menyelesaikan soal cerita khususnya pada materi perbandingan sub materi perbandingan senilai dan berbalik nilai. Strategi yang digunakan merupakan strategi yang benar dalam menyelesaikan soal pernalaran proporsional namun secara umum siswa tidak tahu alasan penggunaan strategi tersebut atau tidak bisa menjawab secara konseptual. Secara umum level penalaran proporsional siswa berada pada level 1 atau level penalaran kualitatif. Hanya satu siswa yang berada pada level 5 atau level penalaran multiplikatif.

\section{DAFTAR PUSTAKA}

Bire, A. L., Geradus, U., \& Bire, J. (2014). Pengaruh Gaya Belajar Visual, Auditorial, dan Kinestetik Terhadap Prestasi Belajar Siswa. Jurnal Kependidikan: Penelitian Inovasi Pembelajaran, 44(2), 168-174. doi:10.21831/jk.v44i2.5307

Irpan, S. (2010). Proses Terjadinya Kesalahan dalam Penalaran Proposional Berdasarkan Kerangka Kerja Asimilasi dan Akomodasi. Beta: Jurnal Tadris Matematika, 3(2), 100-117.

Marpaung, J. (2016). Pengaruh Gaya Belajar Terhadap Prestasi Belajar Siswa. KOPASTA: Jurnal Program Studi Bimbingan Konseling, 2(2).

Nugraha, Y., Sujadi, I., \& Pangadi, P. (2016). Penalaran Proporsional Siswa Kelas VII. Beta: Jurnal Tadris Matematika, 9(1), 34-47. doi:10.20414/Betajtm.V9i1.2

Parbawa, I. G. N. M. A. (2018). Pengaruh Model Pembelajaran Visual Auditory Kinestetik dan Motivasi Belajar Terhadap Kompetensi Pengetahuan IPS Siswa Kelas IV SD Gugus Srikandi Denpasar Timur Tahun Pelajaran 2016/2017. Jurnal Ilmiah Sekolah Dasar, 2(1), 69-74.

Putra, A., Syarifuddin, H., \& Zulfah, Z. (2018). Validitas Lembar Kerja Peserta Didik Berbasis Penemuan Terbimbing dalam Upaya Meningkatkan Pemahaman Konsep dan Kemampuan Penalaran Matematis. Edumatika: Jurnal Riset Pendidikan Matematika, 1(2), 56-62. doi:10.32939/ejrpm.v1i2.302

Putri, F., Amelia, F., \& Gusmania, Y. (2019). Hubungan Antara Gaya Belajar dan Keaktifan Belajar Matematika Terhadap Hasil Belajar Siswa. Edumatika: Jurnal Riset Pendidikan Matematika, 2(2), 83-88. doi:10.32939/ejrpm.v2i2.406

Sari, I. P., \& Sufri, S. (2014). Analisis Penalaran Proporsional Siswa Dengan Gaya Belajar Auditori Dalam Menyelesaikan Soal Perbandingan Pada Siswa SMP Kelas VII. Edumatica: Jurnal Pendidikan Matematika, 4(2), 48-55. doi:10.22437/edumatica.v4i02.2070 
Suryadi, S. (2017). Analisis Penalaran Proporsional Siswa Kelas VIII Berdasarkan Gaya Kognitif Field Dependent dan Field Independent pada Materi Bangun Ruang. EKUIVALEN-Pendidikan Matematika, 30(3).

Wulansari, T., Putra, A., Rusliah, N., \& Habibi, M. (2019). Pengaruh Model Pembelajaran Berbasis Masalah pada Materi Statistika Terhadap Kemampuan Penalaran Statistik Siswa. AKSIOMA: Jurnal Matematika dan Pendidikan Matematika, 10(1), 35-47. doi:10.26877/aks.v10i1.3647 